\title{
Host Range Studies of the Virus Causing Mosaic Disease in Soybean
}

\author{
Y.S. Balgude*, S.R. Zanjare and A.V. Suryawanshi \\ Seed Technology Research Unit, Mahatma Phule Krishi Vidyapeeth, Rahuri \\ Dist. Ahmednagar, Maharashtra State, Pin-413 722, India \\ *Corresponding author
}

\begin{tabular}{l} 
Ke y w o r d s \\
$\begin{array}{l}\text { Soybean, Mosaic } \\
\text { disease, Host } \\
\text { range, Diagnostic } \\
\text { hosts, SMV }\end{array}$ \\
\hline Article Info \\
$\begin{array}{l}\text { Accepted: } \\
12 \text { December } 2020 \\
\text { Available Online: } \\
\text { 10 January } 2021\end{array}$ \\
\hline
\end{tabular}

Among the twenty five plant species belonging to different families viz., Chenopodiaceae, Leguminosae, Cucurbitaceae, Malvaceae, Amaranthaceae, Compositae and Solanaceae, only five species from Leguminosae family were systemically infected by virus causing mosaic disease of Soybean and the per cent transmission of the present virus varies from 70 - 100 per cent as per host species. Chenopodium amaranticolor and C. quinoa from Chenopodiaceae family which showed chlorotic local lesions (CLL) was the only two assay host. The remaining plant species in families viz., Leguminosae, Solanaceae, Cucurbitaceae, Malvaceae, Compositae and Amaranthaceae neither showed any symptom reaction nor the virus was recovered from them by back indexing on $C$. amaranticolor. The systemic symptoms produced by the virus upon mechanical inoculation on soybean were similar to those produced by plants infected naturally. In soybean the virus isolate exhibited vein clearing, mosaic mottling, puckering, distortion and curling of leaves and stunting of plants. Bean, cowpea and cluster bean showed mosaic mottling symptoms while dolichos bean showed necrotic local lesions. Thus, on the basis of symptomatology reaction the present virus was tentatively identified as soybean mosaic virus (SMV).

\section{Introduction}

Soybean [Glycine $\max$ (L.) Merrill], 'Queen of Pulses ', a native of Eastern Asia belongs to the family Leguminosae, subfamily Papilionoideae and tribe Phaseolae. Soybean is considered as a 'Golden bean', 'Miracle bean', 'Agriculture's Cinderella' and 'Wonder crop of the $20^{\text {th }}$ Century' due to its qualities such as high protein (40\%), good amount of carbohydrates (35\%), oil (20\%) and ash (5\%) content on oven dry basis. In India, soybean is mainly grown in the states of Madhya Pradesh, Maharashtra, Rajasthan, Karnataka, Andhra Pradesh, Chattisgarh, Nagaland and Gujarat as a rainfed crop during the rainy (Kharif) season.

Soybean is severely attacked about half a dozen of major diseases, a dozen of insect 
pest and several major weeds causing losses from 20 to 100 percent (Annymous, 2014). The major diseases on soybean generally observed are rust, Fusarium wilt, Sclerotium wilt, brown leaf spot (Septoria glycines) and bacterial blight (Pseudomonas glycines), mosaic etc. Out of these diseases, mosaic disease is becoming the main constrain in successful production of soybean.

The viruses involved in the mosaic disease of soybean are soybean mosaic virus (SMV) cowpea aphid borne mosaic virus, peanut mottle virus (PMV) and cowpea mild mottle virus (CMMV) (Mali, 1995).

During Kharif 2018 in Rahuri the natural infection of viral disease characterized by vein clearing, mosaic, mottling on leaves was noticed. Due to the maximum severity of the viral infection, the present investigation on host range studies was undertaken to identify the virus associated with the symptoms.

\section{Materials and Methods}

Twenty five selected species belonging to different families viz., Chenopodiaceae, Leguminosae, Cucurbitaceae, Malvaceae, Amaranthaceae, Compositae and Solanaceae were tested for host range studies.

Twenty plants from each host species were raised from healthy seed and sown in earthen pots containing steam sterilized soil, compost and sand (2:1:I) mixture and plants were inoculated with the sap extracted from virus infected soybean leaves by conventional leaf rub method at their appropriate growth stage and maintain in an insect free glass house. Leaves of inoculated plants were observed for 4-6 weeks for symptom development. Both the type of plants which are showing symptoms or the plants not showing any type of symptoms for 4-6 weeks were back indexed on assay host Chenopodium amaraticolor for detection of latent infection, if any.

\section{Results and Discussion}

Host range of the virus on 25 plant species belonging to seven different families revealed that the yirus infect systemically only five species of Leguminosae family apart from Chenopodium amaraticolor and $C$. quinoa (Table 1). However, eighteen plant species belonging to five different families were not infected by the present virus. Likewise, the host range of present virus, several workers reported that the host range of Soybean Mosaic Virus (SMV) is also restricted to the members of leguminosae only (Galvez, 1963, Hill, 1999 and Hajong et al., 2018)

On inoculation of virus isolate of soybean, the initial symptoms of yellowish vein clearing were appeared 6-7 days of inoculation. Later severe vein clearing, mosaic mottling, puckering and curling of leaves appeared in 10-13 days of inoculation. Primary leaves of plants showed curling, internodes and petioles shortened resulting in stunted growth of plants. The seed coat of seeds collected from inoculated plants got mottled and shriveled. Bean, cowpea and cluster bean showed mosaic mottling symptoms while dolichos bean showed necrotic local lesions.

Maximum infection of 100 per cent was noticed in soybean while 80 per cent infection was recorded in dolichos bean. The bean and cowpea showed 75 per cent infection while 70 per cent infection was shown by cluster bean.

Chenopodium amaranticolor and $C$. quinoa from Chenopodiaceae family was the only host which were locally infected showing chlorotic local lesions 5-9 days after inoculation and the per cent of transmission was upto 100 per cent. 
Table.1 Host range of virus causing mosaic disease in soybean

\begin{tabular}{|c|c|c|c|c|c|c|c|c|c|c|}
\hline \multirow[t]{2}{*}{$\begin{array}{l}\text { Sr. } \\
\text { No. }\end{array}$} & \multirow[t]{2}{*}{ Host } & \multicolumn{4}{|c|}{ Reactions } & \multicolumn{2}{|c|}{$\begin{array}{c}\text { Virus recovery on } \\
\text { soybean }\end{array}$} & \multicolumn{2}{|c|}{$\begin{array}{l}\text { Virus recovery on } \\
\text { C. amaranticolor }\end{array}$} & \multirow[t]{2}{*}{ Remark } \\
\hline & & Local & Systemic & $\begin{array}{c}\text { Incubation } \\
\text { Period (Days) }\end{array}$ & $\begin{array}{c}\text { Transmission } \\
(\%)\end{array}$ & Local & Systemic & Local & Systemic & \\
\hline \multicolumn{11}{|c|}{ Leguminosae } \\
\hline 1. & $\begin{array}{l}\text { Soybean (Glycine } \max \\
\text { (L.) Merr.) }\end{array}$ & -- & $\begin{array}{l}\text { SVC, LC, } \\
\text { MOT, PUCK, } \\
\text { DIST, ST }\end{array}$ & $10-13$ & 100 & -- & + & + & -- & SH \\
\hline 2. & $\begin{array}{l}\text { Bean (Phaseolus } \\
\text { vulgaris L.) }\end{array}$ & -- & $\mathrm{MM}$ & $18-20$ & 75 & -- & + & + & -- & $\mathrm{SH}$ \\
\hline 3. & $\begin{array}{l}\text { Cowpea (Vigna } \\
\text { unguiculata L.) }\end{array}$ & -- & MM & $22-24$ & 75 & -- & + & + & -- & SH \\
\hline 4. & $\begin{array}{l}\text { Clusterbean }(C . \\
\text { tetragonoloba Traub.) }\end{array}$ & -- & $\mathrm{MM}$ & $20-22$ & 70 & -- & + & + & -- & $\mathrm{SH}$ \\
\hline 5. & $\begin{array}{l}\text { Dolichos bean (Lablab } \\
\text { purpureus L.) }\end{array}$ & NCL & -- & $20-24$ & 80 & -- & + & + & -- & $\mathrm{SH}$ \\
\hline \multicolumn{11}{|c|}{ Chenopodiaceae } \\
\hline 6. & $\begin{array}{l}\text { Chenopodium } \\
\text { amaranticolor }\end{array}$ & CLL & -- & $5-9$ & 100 & -- & -- & -- & -- & LH \\
\hline 7. & C. quinoa & CLL & -- & $5-9$ & 100 & -- & -- & -- & -- & LH \\
\hline & $\begin{array}{l}* \text { MOT : Mottling } \\
\text { DIST : Distortion } \\
\text { LH : Local host }\end{array}$ & & $\begin{array}{l}: \text { Mild vein clearin } \\
\mathrm{T} \quad: \text { Stunting } \\
\mathrm{I}=\text { Systemic host }\end{array}$ & $\begin{array}{r}\mathrm{PUCl} \\
\mathrm{NCL}: \mathrm{Ne}\end{array}$ & $\begin{array}{l}\mathrm{X} \text { : Puckering } \\
\text { crotic local Lesion }\end{array}$ & & $\begin{array}{l}\text { : Leaf Curlin } \\
: \text { Mosaic mo }\end{array}$ & & $\begin{array}{l}\text { SVC: Severe } \\
\text { CLL: Chlorot }\end{array}$ & $\begin{array}{l}\text { ein clearing } \\
\text { local lesions }\end{array}$ \\
\hline
\end{tabular}


Vicia faba, Vigna radiate, Pisum sativum, Arachis hypogaea, Chenopodium murale, Nicotiana tabacum, N. glutinosa, Capsicum annum, Lycopersicon esculentum, Datura stramonium, Luffa cylindrica, Cucumis sativus, Lagenaria siceraria, Memordica charantia, Abelmoschus esculentus, Gomphrena globosa, Helianthus annus and Carthamus tinctorious neither showed any symptom reaction nor the virus was recovered from them by back indexing on $C$. amaranticolor.

Similar host range has been reported by several workers in case of soybean mosaic caused by soybean mosaic virus (Lekveishvili and Chaduneli, 1979; Anjos et al., 1985; Shafik and Jubori, 1987, Singh and Gupta, 1996 and Balgude et al., 2012). On the basis of symptomatology reaction on diagnostic hosts and host range, the present virus tentatively identified as soybean mosaic virus ( SMV).

\section{References}

Anjos, J.R.N., Lin, M.T. and Kitajima, E.O. 1985 Characterization of an isolate of soybean mosaic virus. Fitopatol. Bras. 10(1): 143-157.

Anonymous. 2014. Integrated pest management package for soybean. Ministry of Agriculture, Department of Agriculture \& Cooperation, Directorate of Plant Protection, Quarantine \& Storage, Haryana 121001.

Balgude YS, Sawant DM, Gaikwad AP. Studies on mosaic disease of soybean variety MASC-13. J. Pl. Dis. Sci. 2012; $7(1): 48-51$.
Galvez, G.E. 1963. Host range, purification, and electron microscopy of Soybean mosaic virus. Phytopathology. 53: 388393.

Hajong, M., Atram, P.C. and Mane, S.S. 2018. Sap Transmission and Host Range Study of Soybean Mosaic Virus in Soybean. Int.J.Curr.Microbiol. App.Sci. 7(08): 795-800. doi: https://doi.org/10.20546/ijcmas.2018.70 8.089

Hill, J.H. 1999. Soybean Mosaic Virus. In: "Compendium of Soybean Diseases". 4th Ed., Hartman, G.L., Sinclair, J.B. and Rupe, J.C. (Eds.). The American Phytopathological Society, St. Paul, Minnesota. Pp. 70- 71.

Lekveishvili, R.I. and Chaduneli, M.D. 1979. Investigation on soybean mosaic in Georgia. Trandy Nauchno Issledovated'skogo Instituta Zashchity Rastenii Gruz. 29: 45-47.

Mali, V.R. 1995. Profile of viruses naturally infecting soybean in Marathawada. Abstracts and Souvenir, Tenth Annu. Conv. Indian Virol. Soc. And National Symposium: Viral Diseases of SocioEconomic Importance Relevant to India, Jan.16-18, 1995. SCTIMST, Dept. Microbiol, Trivandrum, India, p34.

Shafik, H.L. and Jubori, A.D.1987. Identification of soybean mosaic virus on Soybean in Iraq. J. Agriculture and Water Resources Research. Plant Production. 6(2): 43-52.

Singh, R.P. and Gupta, P.1996. Natural occurrence of soybean mosaic virus on Coffee senna. Indian J. Virol. 12(1): 7172.

\section{How to cite this article:}

Balgude, Y.S., S.R. Zanjare and Suryawanshi, A.V. 2021. Host Range Studies of the Virus Causing Mosaic Disease in Soybean. Int.J.Curr.Microbiol.App.Sci. 10(01): 1821-1824. doi: https://doi.org/10.20546/ijcmas.2021.1001.212 